\title{
Histological Changes in Liver and Kidney of Clarias gariepinus (Burchell, 1822) Juvenile Exposed to Sub-lethal Doses of Chloramphenicol (CAP)
}

\author{
Peter J. Nkwuda ${ }^{1}$, Jude S. Awoke ${ }^{1, *} \mathbb{D}^{\mathbb{D}}$, Joseph N. Nwakpa ${ }^{1}$ \\ ${ }^{1}$ Ebonyi State University, Department of Fisheries and Aquaculture, P.M.B. 053 Abakaliki, Nigeria.
}

\author{
Article History \\ Received 07 December 2019 \\ Accepted 31 March 2020 \\ First Online 02 April 2020

\section{Corresponding Author \\ Tel.: +23460517022 \\ E-mail: \\ judeawoke786@yahoo.com}

\section{Keywords}

Sub-lethal

Bioconcentration

Bioaccumulation

Antibiotic

Necrosis

\begin{abstract}
A 70 days study was carried out on the effect of Chloramphenicol (CAP) on the liver and kidney tissues of Clarias gariepinus juveniles using static renewal bioassay techniques. Two hundred and seventy fish with mean length $7.39 \pm 39 \mathrm{~cm}$ and mean weight $12.37 \pm 65 \mathrm{~g}$ were exposed to sub lethal concentrations of chloramphenicol. Sublethal concentrations used were $T_{1}(20 \mathrm{mg} / \mathrm{l}), T_{2}(40 \mathrm{mg} / \mathrm{l}), T_{3}(60 \mathrm{mg} / \mathrm{l}), T_{4}(80 \mathrm{mg} / \mathrm{l})$ and $T_{5}(100 \mathrm{mg} / \mathrm{l})$ while $T_{0}(0 \mathrm{mg} / \mathrm{l})$ served as the control. The liver and kidney were removed for histopathological examinations. Observed histopathological changes in the liver and kidney were intra-hepatic hemorrhage, hypertrophic hepatocytes, tissue degeneration, cytoplasmic vacoulation, cellular necrosis, occlusion of tubular lumen, expansion of glomerulus, reduction of Bowman's space. Effect was most severe at the highest concentration (100 $\mathrm{mg} / \mathrm{l})$. Observed abnormalities in the liver and kidney of Clarias gariepinus juveniles illustrate the suitability of Clarias gariepinus in toxicity trials of antibiotics.
\end{abstract}

\section{Introduction}

The antibiotic drug chloramphenicol with molecular formular $\left(\mathrm{C}_{11} \mathrm{H}_{12} \mathrm{CL}_{2} \mathrm{~N}_{2} \mathrm{O}_{5}\right)$ and molecular weight $(323.126 \mathrm{~g} / \mathrm{mol})$ is one of the antibiotic drugs used widely in the farming of aquatic animals to treat diseases and increase productivity (Sarwer et al., 2017). It is used in most cases for prophylactic and therapeutic conditions in aquaculture because of its broad-spectrum activities against gram negative and gram-positive bacteria. It is bacteriostatic in action through the inhibition of the growth of pathogenic bacteria. Antibiotics are constructed to act in one of three ways: by disrupting the cell membranes of bacteria, by impeding DNA or protein synthesis, and by hampering the activity of certain enzymes unique to bacteria (Angulo, 2000).
Due to continual detection of some antibiotic drugs in the aquatic environment and in food products, it calls for serious concern due to their high rate of carcinogenicity and non-biodegradability. In recent times, wide ranges of these compounds at various concentrations have been found in different environmental media and in tissues of both freshwater and marine fishes as a result of bioaccumulation (Manoraham, 2014). It has been discovered that even at minimal level of concentrations, these compounds are deleterious to living organisms (Jonathan \& Nicolas, 2005), including humans. Amrevuawho et al. (2016) alerted that escalating uses of various antibiotics acting as xenobiotic chemicals in fish farms have resulted in a rise in bioconcentration and bioaccumulation in the tissue of aquatic animals. The xenobiotic compounds usually concentrate in the tissue of aquatic biota and are 
known to produce cumulative deleterious effects (Solbe, 1995, Rahman et al., 2002).

Therefore, investigations using histopathological results have been noted as dependable indications to evaluate the toxic effect of toxins in organs of fish (Van der Oost et al., 2003). The abnormality discovered has long been applied in the examination of the health of fish under chronic and acute exposure to toxic materials. The use of histopathological results in environmental assessment and monitoring is essential because it helps to detect the affected parts in those functional organs of the fish (Gernhofer et al., 2001). The changes discovered in the particular organ can be used to predict the possible dangers to the health of animals (Hinton \& Laurén, 1990).

Liver and kidney of fish are responsible for detoxification, elimination and absorption of substances into their internal systems and any damage to these organs can lead to malfunctions. Liver is responsible for the detoxification and biotransformation processes because of its performance, location and active involvement in production of blood (Van der Oost et al., 2003). The kidney as well is responsible for osmoregulation and excreting toxicants from the blood. These organs are mostly distressed by toxicants in the aquatic environment (Rodrigues \& Fanta, 1998) because of its active involvement in biological activities. The monitoring and evaluation of histopathological distortion in fish organs is a good method for determining the side-effects of antibiotic drugs in the field and laboratory experiments. Consequently, the use of antibiotic toxicological studies on aquatic organisms is imperative to appraise its noxious effect in the internal organs.

The African Catfish, C. gariepinus belongs to the family Clariidae (Airbreathing catfishes), order Siluriformes (catfish). There are over hundred species in this family occurring naturally throughout most of Africa and the Southern half of Asia to Java and the Philippines (Teugels, Sudarto and Pouyaud, 2001). The experimental fish, $C$. gariepinus was used for this study because it is the most sought-after species among fish farmers and consumers. Besides, it commands good commercial value not only Nigeria but all over Africa (Dienye and Olumuji, 2014). Many of the species are of great economic importance in both fisheries and fish culture. It can tolerate a large variety of feedstuffs and is very resistant to changing and suboptimal water conditions. Furthermore, it can be cultivated in high densities reaching production levels of 6 to $16 \mathrm{MT} / \mathrm{ha}$ (Faturoti, 1989).

Nonetheless, there is shortage of knowledge on the evaluations of toxicological effect of chloramphenicol on the histopathology of the liver and kidney of C. gariepinus. Hence, this study was carried out to determine the effect of sublethal concentrations of chloramphenicol on the histopathological samples of the liver and kidney of African catfish C. gariepinus juveniles.

\section{Materials and Methods}

\section{Experimental Site}

The experiment was conducted at the wet laboratory, Department of fisheries and Aquaculture, Ebonyi State University, Abakaliki, Ebonyi State, Nigeria. Ebonyi State is situated is situated between latitudes 6.24 $\mathrm{ON}$ and 6.28 $\mathrm{ON}$ and longitudes 7.00 OE and 7.06 OE on the South- Eastern part of Nigeria.

\section{Experimental Fish}

The experimental fish, $C$. gariepinus (juveniles) with mean length $39 \pm 7.39 \mathrm{~cm}$ and mean weight $65 \pm$ $12.37 \mathrm{~g}$ were procured from Chiboy Integrated Fish Farm, Abakaliki, Ebonyi State. A total of two hundred and seventy African catfish C. gariepinus (juveniles) were transported in plastic container to the Wet Laboratory of the Department of Fisheries and Aquaculture, Ebonyi State University, Abakaliki, Ebonyi State. The fish were acclimated for 2 weeks under laboratory conditions in 70 litres capacity plastic vats before the commencement of the study and were fed with commercial feed.

\section{Preparation of Chloramphenicol Solution}

Chloramphenicol capsules (250mg) containing chloramphenicol sodium succinate as the active ingredient and manufactured by Jiangsu Huayang Pharmaceutical Company, China were used to prepare the stock solution. Six hundred and fifty (650) capsules of chloramphenicol were decapsulated and stored in an airtight container. The chloramphenicol powder was thereafter dissolved in dechlorinated water to prepare the stock solution. Later on, the calculated amount of stock solution was added to the experimental units by serial dilution method so as to get the desired sub lethal test concentrations.

\section{Experimental Design}

The fish were randomly distributed into the plastic vats containing dechlorinated water in a completely randomized design (CRD). During the period of acclimation and the experiment, the fish were fed with commercial feed (Coppens) on $45 \%$ crude protein diet at $5 \%$ body weight twice daily (8.00am and $4.00 \mathrm{pm}$ ) throughout the period of acclimation and experiment. It is from the acclimated fish that the test fish were selected for bioassay studies. Mortality did not exceed $5 \%$ during acclimation period. Sublethal concentrations of chloramphenicol used were $\mathrm{T}_{1}(20 \mathrm{mg} / \mathrm{l}), \mathrm{T}_{2}(40 \mathrm{mg} / \mathrm{l})$, $\mathrm{T}_{3}(60 \mathrm{mg} / \mathrm{l}), \mathrm{T}_{4}(80 \mathrm{mg} / \mathrm{l})$ and $\mathrm{T}_{5}(100 \mathrm{mg} / \mathrm{l})$. During the 
exposure period, 10 fish each was introduced into the $70 \mathrm{~L}$ capacity plastic vats containing $30 \mathrm{~L}$ of well aerated dechlorinated tap water. The already prepared concentrations were introduced into the first five plastic vats serially, representing five treatments while the sixth treatment $T_{0}(0 \mathrm{mg} / \mathrm{l})$ served as the control (devoid of the solution of chloramphenicol). Each treatment had three replications. Water in each tank was replaced every three days throughout the period to prevent fouling resultant from fecal matter and feed remnants. Chloramphenicol powder was reintroduced in the culture water at the same varying concentrations along side. The experiment lasted for the period of 70 days, during which methods of renewal bioassay test were employed in this investigation. No mortality record occurred throughout the research. During the exposure temperature, dissolved oxygen, $\mathrm{pH}$, total hardness, ammonia, alkalinity, nitrate and nitrite were monitored every 24 hrs according to methods described by APHA (2002).

\section{Histopathological Analysis}

Abdominal cavities of sacrificed fish were dissected to collect the liver and kidney for histopathological analysis. The organs collected were fixed in $10 \%$ formalin to avoid autolysis and safeguard cells in vitro.

\section{Tissue Processing (Dehydration, Dealcoholization and Infiltration)}

The tissues were processed in an automatic tissue processor (Model-Leica AP). The tissues were first processed by putting it in tissue cassette and dehydrated in graded alcohol of $70-100 \%$ and the alcohol was removed with xylene (Bancroft \& Stephen, 1990). The clearing agents were replaced by passing the tissues through molten paraffin wax maintained at temperature higher than the melting point of wax, to fill the intercellular spaces for easy microtomy.

\section{Embedding (Casting) and Mounting on Wooden Block}

The tissues were embedded in the molten paraffin wax poured inside the Leuckhart embedding metal box and allowed for some minutes to solidify before it was detached. The detached paraffin blocks were mounted on the wooden block with the aid of hot spatula, which melted the portion of the paraffin to be placed on wooden block. The melted part quickly solidified to the wooden block on removing the spatula.

\section{Microtomy, Sectioning and Microphotography}

The wooden blocks were screwed to the microtome chuck and paraffin block trimmed to expose embedded tissues and then sectioned at $6 \mu \mathrm{m}$ with a rotator microtome (Leica $\mathrm{Rm} 2135$ ) Sectioned tissues were stained with heamatoxylin and eosin using the method of Bancroft and Stehpen (1990). Microphotography of the sectioned tissues produced photomicrograph of cells of chloramphenicol exposed tissues with control with the use of microscope. This procedure was conducted at the histopathology laboratory, Federal Teaching Hospital (FETHA) Abakaliki Ebonyi State, Nigeria.

\section{Statistical Analysis}

Results obtained from investigation were subjected to one-way analysis of variance (ANOVA) using the Statistical package for social sciences (SPSS version 20) to determine the significant difference between the various treatments and control. Duncan Multiple Range Test was used to separate the difference among the means and the differences were considered significant at $(P>0.05)$.

\section{Results}

\section{Water Quality Analysis}

Result from water quality analysis shows that the mean water quality parameters obtained in the treatment tanks did not vary significantly $(P>0.05)$ from those of the control tanks (Table 1). All were within the suggested tolerance ranges. No mortality was recorded during the experimental period.

\section{Histopathology of the Liver}

Results of histological analysis of the liver of $C$. gariepinus juveniles exposed to Sub-lethal concentration of chloramphenicol for 70 days are

Table 1. Result of Water Quality Parameters during 96 Hours Exposure of Clarias gariepinus Juveniles to Sub lethal Concentrations of chloramphenicol*

\begin{tabular}{|c|c|c|c|c|c|c|}
\hline & CONTROL & T1 & T2 & T3 & T4 & T5 \\
\hline PARAMETERS & $0 \mathrm{mg} / \mathrm{l}$ & $20 \mathrm{mg} / \mathrm{l}$ & $40 \mathrm{mg} / \mathrm{l}$ & $60 \mathrm{mg} / \mathrm{l}$ & $80 \mathrm{mg} / \mathrm{l}$ & $100 \mathrm{mg} / \mathrm{l}$ \\
\hline Temperatures $\left({ }^{\circ} \mathrm{C}\right)$ & $24.39 \pm 32^{a}$ & $24.18 \pm 2^{a}$ & $23.24 \pm 4^{a}$ & $23.21 \pm 41^{a}$ & $25.13 \pm 06^{a}$ & $25.54 \pm 30^{a}$ \\
\hline $\mathrm{pH}$ & $6.75 \pm 19 a$ & $7.47 \pm 16^{a}$ & $7.10 \pm 13^{a}$ & $7.01 \pm 13^{a}$ & $6.75 \pm 17^{a}$ & $7.05 \pm 13^{a}$ \\
\hline $\mathrm{DO}(\mathrm{mg} / \mathrm{l})$ & $6.95 \pm 19^{a}$ & $6.85 \pm 23^{a}$ & $6.52 \pm 19^{a}$ & $6.65 \pm 18^{a}$ & $7.30 \pm 08^{a}$ & $6.89 \pm 16^{a}$ \\
\hline Nitrite (mg/l) & $0.03 \pm 00^{a}$ & $0.03 \pm 00^{a}$ & $0.03 \pm 00^{a}$ & $0.03 \pm 00^{a}$ & $0.03 \pm 00^{a}$ & $0.03 \pm 00^{a}$ \\
\hline Nitrate $(\mathrm{mg} / \mathrm{l})$ & $0.01 \pm 06^{a}$ & $0.01 \pm 05^{a}$ & $0.01 \pm 04^{a}$ & $0.01 \pm 004^{a}$ & $0.01 \pm 004^{a}$ & $0.01 \pm 005^{a}$ \\
\hline Ammonia (mg/l) & $0.25 \pm 03^{a}$ & $0.25 \pm 03^{a}$ & $0.25 \pm 03^{a}$ & $0.25 \pm 02^{\mathrm{a}}$ & $0.25 \pm 02^{\mathrm{a}}$ & $0.25 \pm 02^{\mathrm{a}}$ \\
\hline Hardness (mg/l) & $28.0 \pm 02^{\mathrm{a}}$ & $28.0 \pm 02^{\mathrm{a}}$ & $28.0 \pm 02^{\mathrm{a}}$ & $28.0 \pm 02^{\mathrm{a}}$ & $28.0 \pm 02^{\mathrm{a}}$ & $28.0 \pm 02^{\mathrm{a}}$ \\
\hline
\end{tabular}

* Means $( \pm S E)$ of water quality parameters obtained in the treatment tanks did not vary significantly $(P>0.05)$. 
presented in Figure $1 \mathrm{~A}$ to $1 \mathrm{~F}$. Photomicrograph of the liver of $C$. gariepinus in the control group shows normal cell arrangement in Cytoplasm (CP), central nucleus (CN), blood vessels (BV) and intra-hepatic cells (IHC) (Figure 1A). However, photomicrograghs of the Liver of C. gariepinus exposed to Sub lethal concentration of chloramphenicol for 70 days at $20 \mathrm{mg} / \mathrm{l}, 40 \mathrm{mg} / \mathrm{l}, 60 \mathrm{mg} / \mathrm{l}$, $80 \mathrm{mg} / \mathrm{l}$ and $100 \mathrm{mg} / \mathrm{l}$ respectively reveals various degrees of injuries ranging from Necrosis $(N)$, dilation (D) Intracellular hemorrhage (ICH), cytoplasmic vacuolation (CV), hyperplasia (Hy) and tissue degeneration (TD) (Figure $1 \mathrm{~B}$ to $1 \mathrm{~F}$ ). Severity of the lesions tended to rise as the concentration of chloramphenicol increased.

\section{Histopathology of the Kidney}

Results of histological analysis of the kidney of $C$. gariepinus juveniles exposed to Sub-lethal concentration of chloramphenicol for 70 days are presented in Figure $2 \mathrm{~A}$ to $2 \mathrm{~F}$. Figure $2 \mathrm{~A}$ presents the photomicrograph of the Kidney of $C$. gariepinus in control group of fish where glomeruli, bowman's capsules, tubular lumen, blood vessels and intra-renal spaces are well arranged. Figure $2 \mathrm{~B}$ to $2 \mathrm{~F}$ however reveals that the Kidney of $C$. gariepinus exposed to Sub lethal concentrations of chloramphenicol for 70 days at $20 \mathrm{mg} / \mathrm{l}, 40 \mathrm{mg} / \mathrm{l}, 60 \mathrm{mg} / \mathrm{l}, 80 \mathrm{mg} / \mathrm{l}$ and $100 \mathrm{mg} / \mathrm{l}$ respectively shows various degree of injuries which includes: necrosis $(N)$ in the tissue, dilation (D) of the blood vessels, intra-renal hemorrhage (IRH), hyperplasia (Hy) and tissue degeneration (TD). This indicates that the degree of severity of the injuries caused by chloramphenicol in the kidney tended to increase with higher concentrations.

\section{Discussion}

Histopathological examination of fish tissues exposed to toxicants indicates signs of prolonged damage in cells, tissues and organs (Joseph and Nimmy, 2018). Furthermore, histopathological changes have been used as biomarkers to assess the general wellbeing fish exposed to contaminants. The main benefit of making use of such markers in environmental monitoring is that it allows for investigation of critical organs including liver and kidney. These organs are accountable for basic functions such as bioaccumulation and biotransformation of toxicants as well as excretion in fish (Saravpreet et al., 2018).

In the present study, water quality parameters such as temperature, hydrogen ion concentration $(\mathrm{pH})$, nitrate, nitrite, ammonia and hardness were measured every 24 hours (Table 1). The mean water quality parameters obtained in the treatment tanks did not vary significantly $(P>0.05)$ from those of the control tanks. All were within the suggested tolerance ranges. No mortality was recorded during the experimental period.
The liver is composed of hepatocytes that were arranged in layers and were demarcated by endothelium. These investigations also revealed that the liver of untreated fish (Figure $1 \mathrm{~A}$ ) had a normal architectural arrangement of cells and there were no histopathological anomalies. The histopathology of the liver of the exposed fish (Figure 1B-1F) showed different degrees of alterations which includes liver hypertrophy, nucleus hypertrophy, congestion of blood in veins, necrosis and diffusion of melanomacrophages in the parenchymatous tissue of the liver. Vacuolation of cytoplasm and hepatocytes, degeneration of the cells, nucleic damage, stagnation of bile and congestion in the cellular passage were observed in $100 \mathrm{mg} / \mathrm{l}$ of chloramphenicol. The detoxification and biotransformation process occur in the liver because of its performance, location and blood production (Van der Oost et al., 2003) and also affected by toxicants in the aquatic environment (Rodrigues \& Fanta, 1998).

Hypertrophic condition is an enlargement in the size of the cells. Exposition to any contaminant that inflicted proliferations in the membranes of endoplasmic reticulum can be taken as hypertrophic condition (Hinton \& Laurèn, 1990). FigueiredoFernandes et al. (2007) reported that high content of lipids may be as a result of increase in the size of hepatocytes. Similarly, Braunbeck et al. (1990) ascertained that changes in size and shape of nucleus have always been used as signs to show that metabolic activity has been increased and may be associated with pathological sources. Camargo \& Martinez, (2007) reported that vacuoles within the cytoplasm of the hepatocytes contain lipids and glycogen that takes part in metabolic activity of the liver cells. The vacuolization of hepatocytes is an indication that the rate of production of materials in the parenchymal cells and the rate at which it is released into the systemic circulation is not balanced (Gingerich, 1982). Increased vacuolization of the hepatocytes shows remarkable cell degeneration, indicating that damages occurred as a result of direct exposure to polluted water (Pacheco \& Santos, 2002).

Formation of vacuole was described by Mollendroff (1973) as a defensive mechanism of cells to resist the effect of the toxins in the hepatocytes and these mechanisms eliminate harmful compounds, from the cells. The stagnation of bile and dispersion of melanomacrophages within the parenchyma of liver tissues is evidence that this organ suffered from serious injuries both in structural arrangement and metabolic activity resulting from chloramphenicol exposure. According to Hibiya (1982), the stagnation of bile in the hepatocytes, is characterized by tiny particles that are yellowish-brown found inside the cells. This bioaccumulation of bile particles is a sign of damage to the metabolic activities in the hepatic cells (Fanta et al., 2003). An increment in the aggregates of melanomacrophage is a remarkable histological 


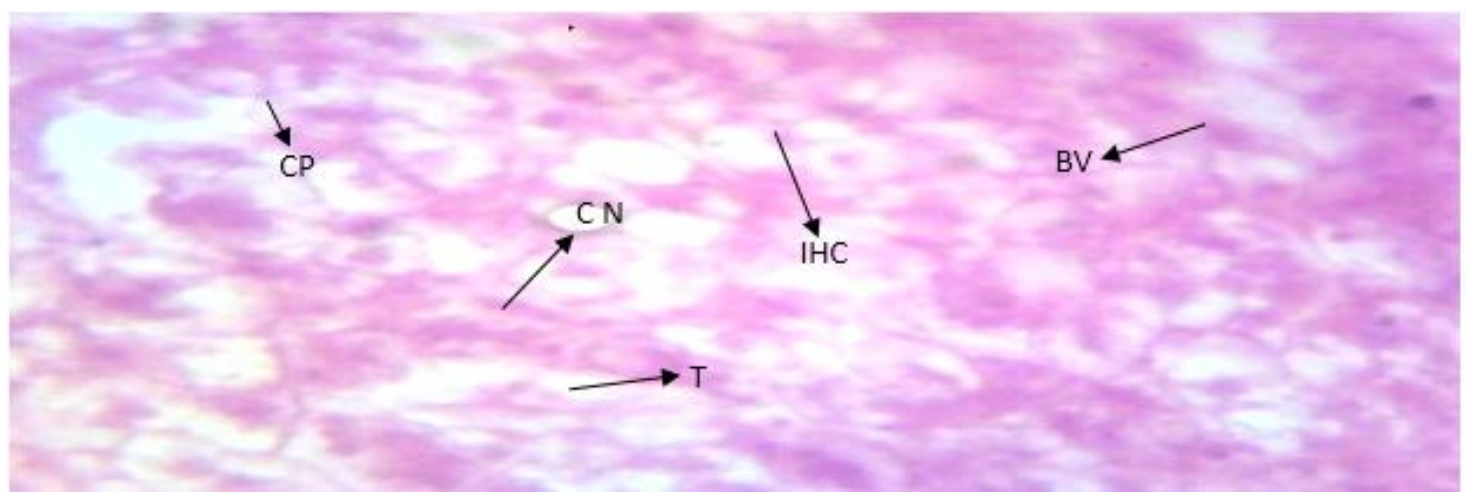

Figure 1A. Photomicrograph of the Liver of Clarias gariepinus in the control group showing normal cell arrangement in Cytoplasm (CP), central nucleus (CN), blood vessels (BV) and intra-hepatic cells (IHC) (Mag.x60).

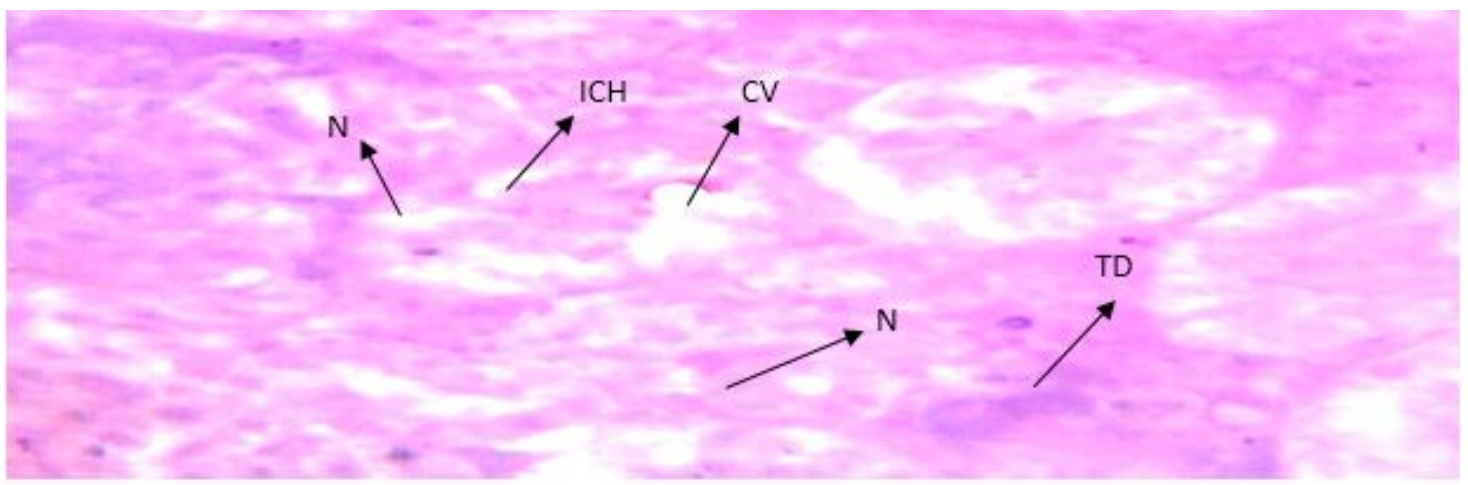

Figure 1B. Photomicrograph of the Liver of $C$. gariepinus exposed to Sub lethal concentration of chloramphenicol for 70 days at 20 $\mathrm{mg} / \mathrm{l}$ showing various degrees of injuries which includes: Necrosis (N), dilation (D) Intracellular hemorrhage (ICH), cytoplasmic vacuolation (CV), hyperplasia (Hy) and tissue degeneration (TD) (Mag.x60).

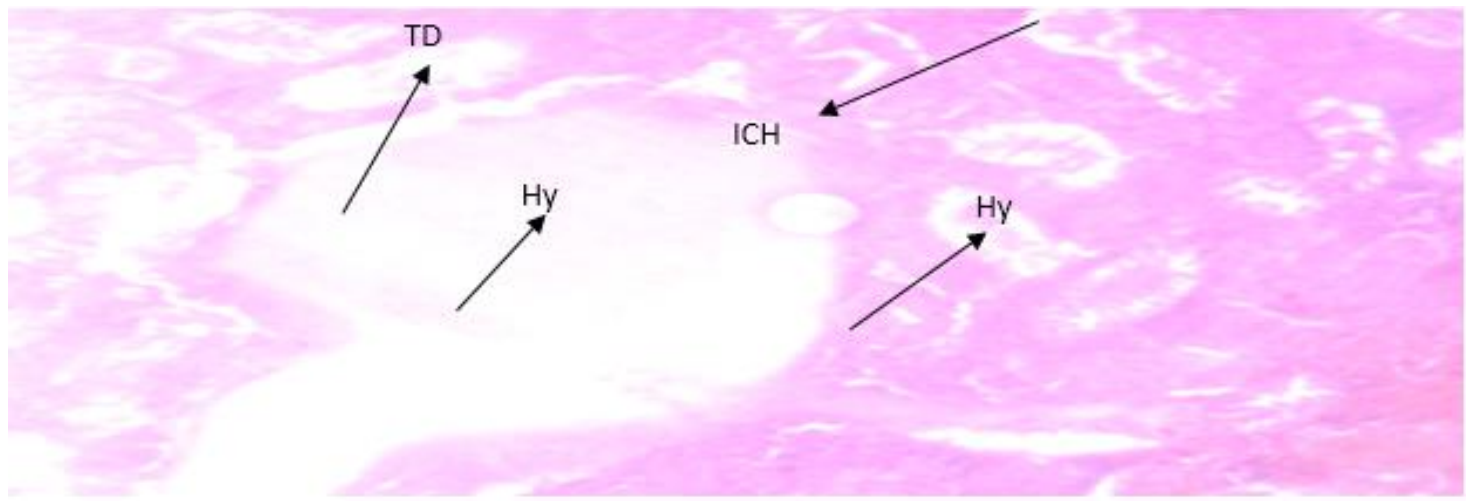

Figure 1C. Photomicrograph of the Liver of $C$. gariepinus exposed to Sub lethal concentration of chloramphenicol for 70 days at 40 $\mathrm{mg} / \mathrm{l}$ showing various degrees of injuries which includes: Necrosis (N), dilation (D) Intracellular hemorrhage (ICH), cytoplasmic vacuolation (CV), hyperplasia (Hy) and tissue degeneration (TD) (Mag.x60).

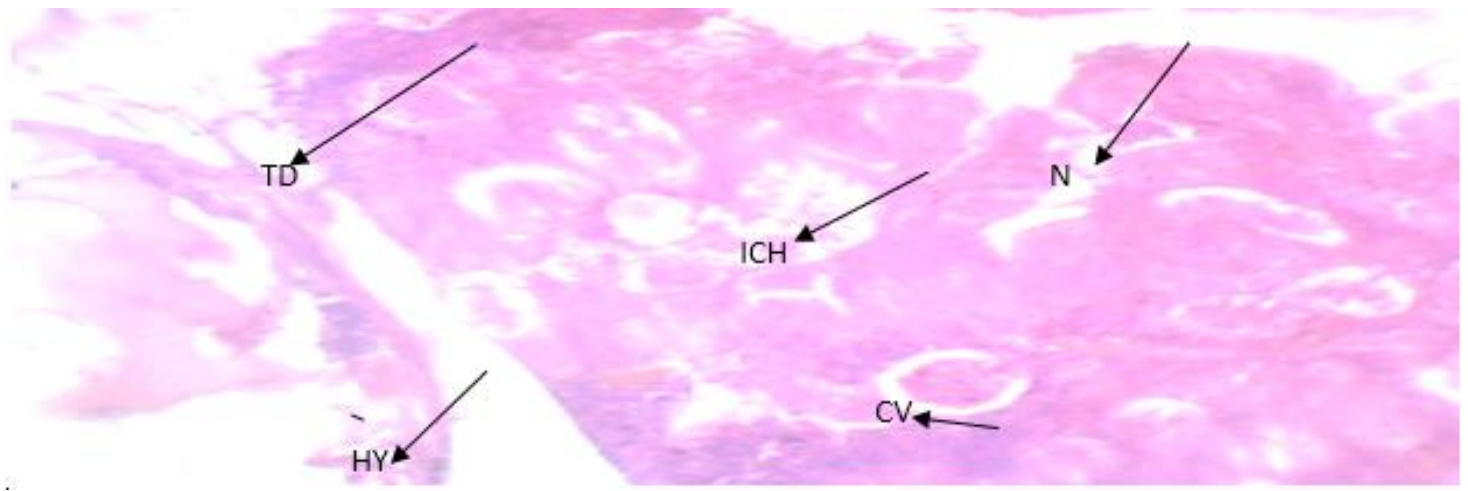

Figure 1D. Photomicrograph of the Liver of Clarias gariepinus exposed to Sub lethal concentration of chloramphenicol for 70days at $60 \mathrm{mg} / \mathrm{l}$ showing various degree of injuries which includes: Necrosis (N), dilation (D) Intracellular hemorrhage (ICH), cytoplasmic vacuolation (CV), hyperplasia (Hy) and tissue degeneration (TD) (Mag.x60). 


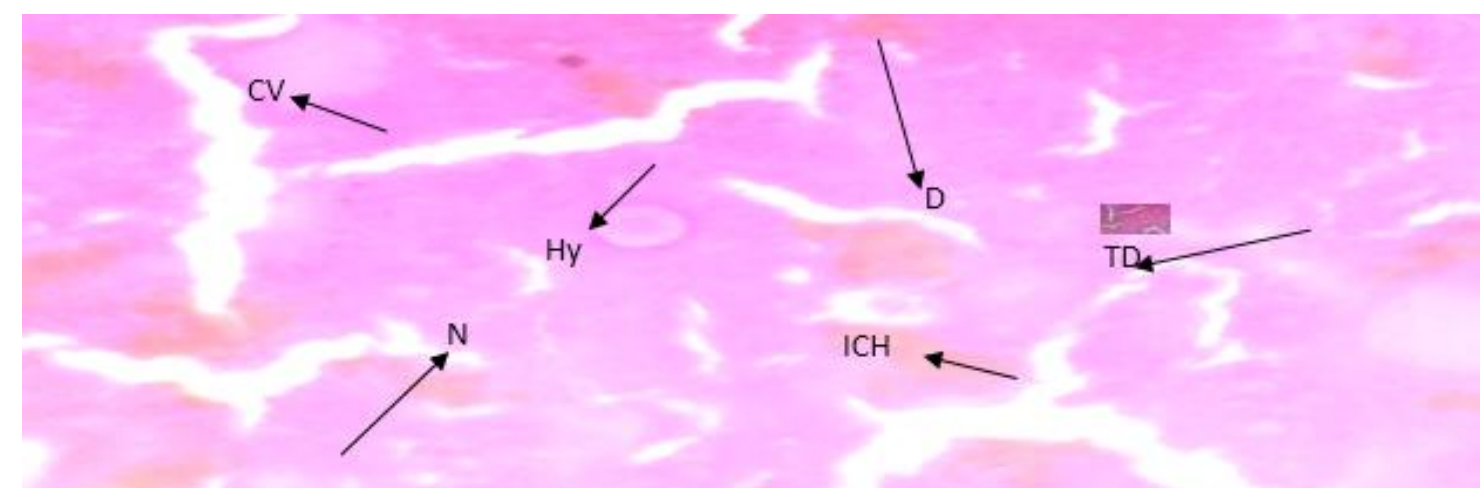

Figure 1E. Photomicrograph of the Liver of Clarias gariepinus exposed to Sub lethal concentrations of chloramphenicol for 70 days at $80 \mathrm{mg} / \mathrm{l}$, showing various degrees of injuries which includes: Necrosis (N), Dilation (D) Intracellular hemorrhage (ICH), cytoplasmic vacuolation (CV), hyperplasia (Hy) and tissue degeneration (TD) (Mag.x60).

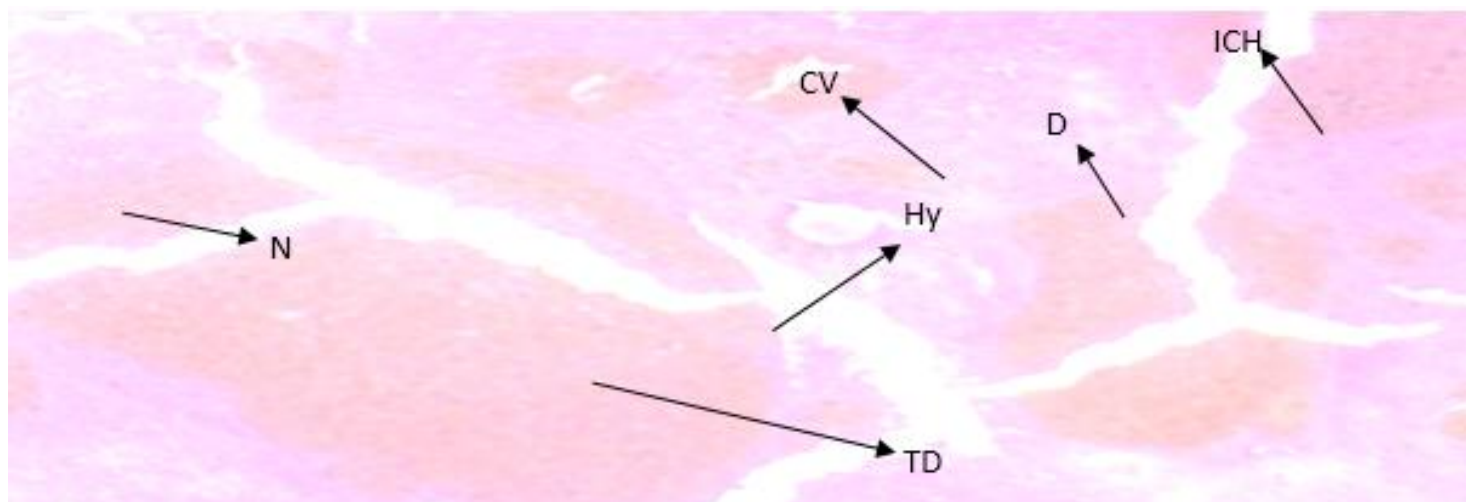

Figure 1F. Photomicrograph of the Liver of Clarias gariepinus exposed to Sub lethal concentrations of chloramphenicol for 70 days at $100 \mathrm{mg} / \mathrm{I}$ showing various degrees of injuries which includes: Necrosis (N), Dilation (D) Intracellular hemorrhage (ICH), cytoplasmic vacuolation (CV), hyperplasia (Hy) and tissue degeneration (TD) (Mag.x60).

anomaly in the hepatic cells (Pacheco \& Santos, 2002), which includes tissue degeneration and necrotic condition. Similar result was reported by Hunter et al. (1980), when rainbow trout, Oncorhynchus mykiss, was exposed to $50 \mu \mathrm{g} / \mathrm{l}$ of aluminum compounds. In addition, the degeneration of the cell and necrotic condition observed may be as a result of cumulative effect of antibiotic compound on hepatic tissue. Fish are been known to bioaccumulate lesser portion of xenobiotic compounds in gills and flesh compared to liver (AlYousuf et al., 2000). Non-biodegradable compounds are been known to have negative interference with cellular metabolism (Rosseland et al., 1990). Sanad et al. (1997) reported that necrosis in the liver cells is as a result of inhibition of DNA production required for cellular maturation of the liver cells. Similarly, contaminated materials are capable of disarranging the structures of the molecule of cellular membranes, resulting to degradation (Byzkowski, 1976).

The histopathology of kidney in control groups were seen to consist of multiple numbers of renal corpuscles, glomeruli and tubular vessels. Histopathological investigations in this research showed normal structural organization of the kidney cells in control treatment of fish (Figure 2A). The histopathology of kidney of the experimental fish $C$. gariepinus was shown in the (Figures 2B - 2F). Results of this research indicated that concentrations of chloramphenicol produced different degrees of histopathological changes in the kidneys of exposed fish. The abnormalities included inconsistency in diameters of renal tubules, expansion of glomeruli, damage in renal corpuscle, severe degeneration in the tubule cells, occlusion of tubular lumen, dilation, oedematous fluid within the tubular cells, hemorrhage and diffusion of erythrocytes. The kidney of $C$. gariepinus is prone to be affected by contaminated materials in the aquatic environment (Thophon et al., 2003). The enlargement in the size of tubular cells observed in this study is referred to as edematous condition. Peebua et al. (2006) made similar observation when Nile tilapia (Oreochromis niloticus) was exposed to contaminants. In biological organization, any interference within the cells by antibiotic drugs can result to cell injuries, such as cell degeneration and neoplastic cell diseases (Pacheco \& Santos, 2002). In more serious conditions, the degenerative processes result to necrosis of tissues (Takashima \& Hibiya, 1995). The occurrence of tubular degeneration and kidney necrosis in this study is evidence that the kidney of $C$. gariepinus juveniles sustained injuries after exposure to chloramphenicol. In this research, $100 \mathrm{mg} / \mathrm{l}$ of chloramphenicol resulted in shrinkage of glomeruli and intracellular hemorrhage. Abdelhamid \& El-Ayouty (1991) reported similar result when catfish, Clarias lazera were exposed to contaminants in aquatic environment. 


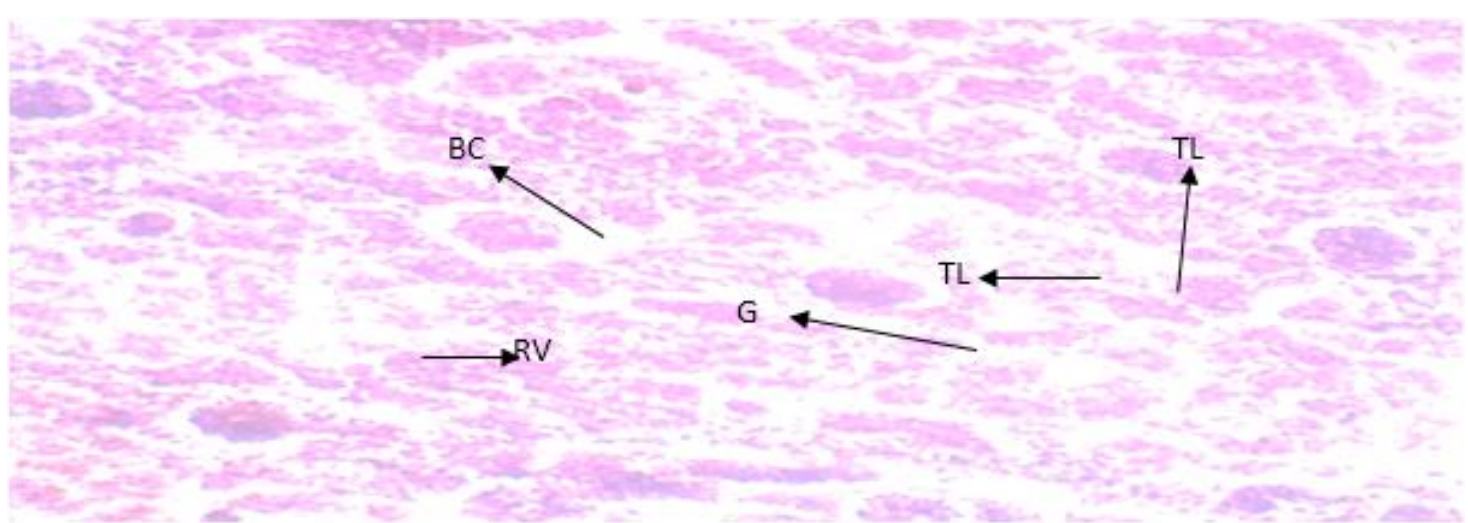

Figure 2A. Photomicrograph of the Kidney of $C$. gariepinus in control group of fish showing Glomeruli, bowman's capsules tubular lumen, blood vessels and intra-renal spaces well arranged (Mag.x60).

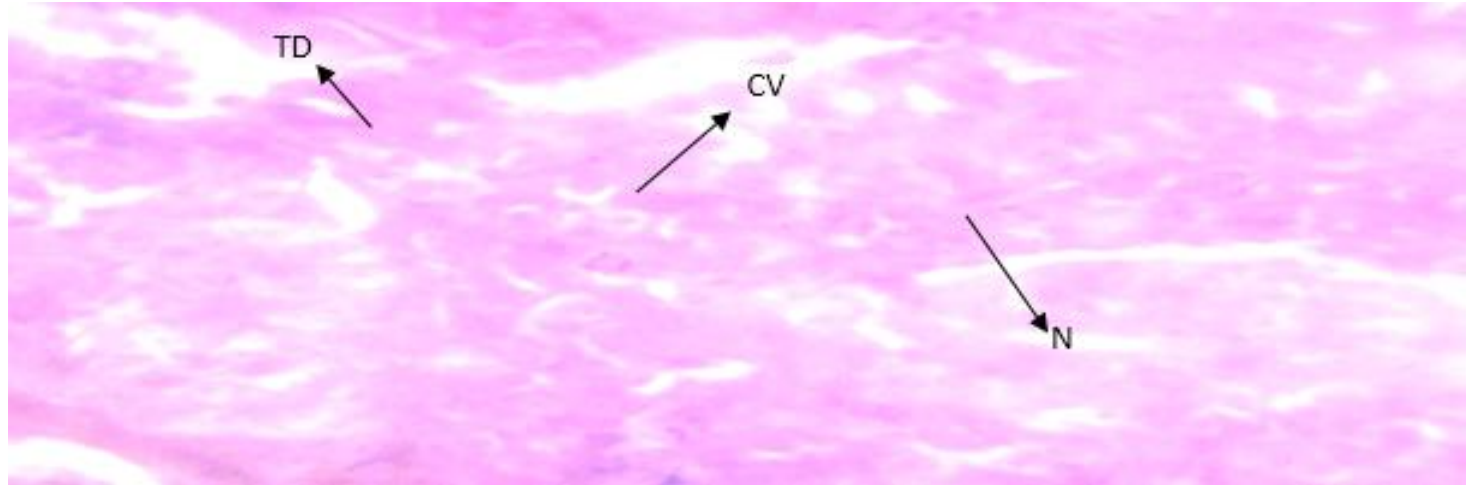

Figure 2B. Photomicrograph of the Kidney of $C$. gariepinus exposed to Sub lethal concentrations of chloramphenicol for 70 days at $20 \mathrm{mg} / \mathrm{l}$ showing various degrees of injuries which includes: necrosis (N), cytoplasmic vacuolation (CV) and tissue degeneration (TD) (Mag.x60).

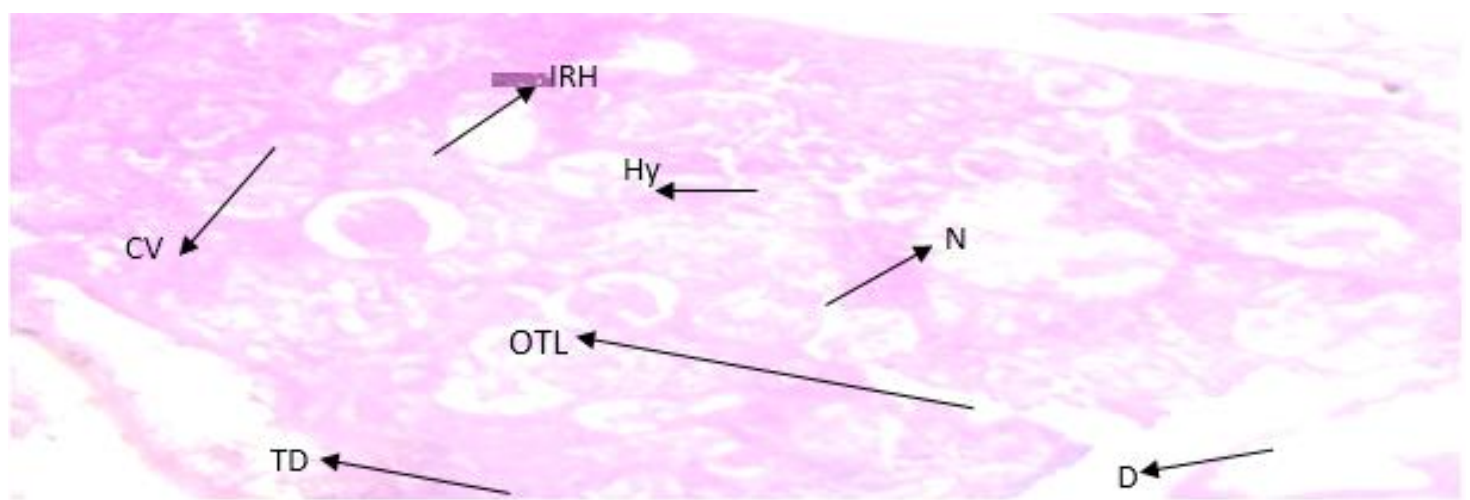

Figure 2C. Photomicrograph of the Kidney of $C$. gariepinus exposed to Sub lethal concentrations of chloramphenicol for 70 days at $40 \mathrm{mg} / \mathrm{l}$, showing various degrees of injuries which includes: necrosis (N), dilation (D) Intra-renal hemorrhage (IRH), cytoplasmic vacuolation (CV), hyperplasia (Hy) and tissue degeneration (TD) (Mag.x60).

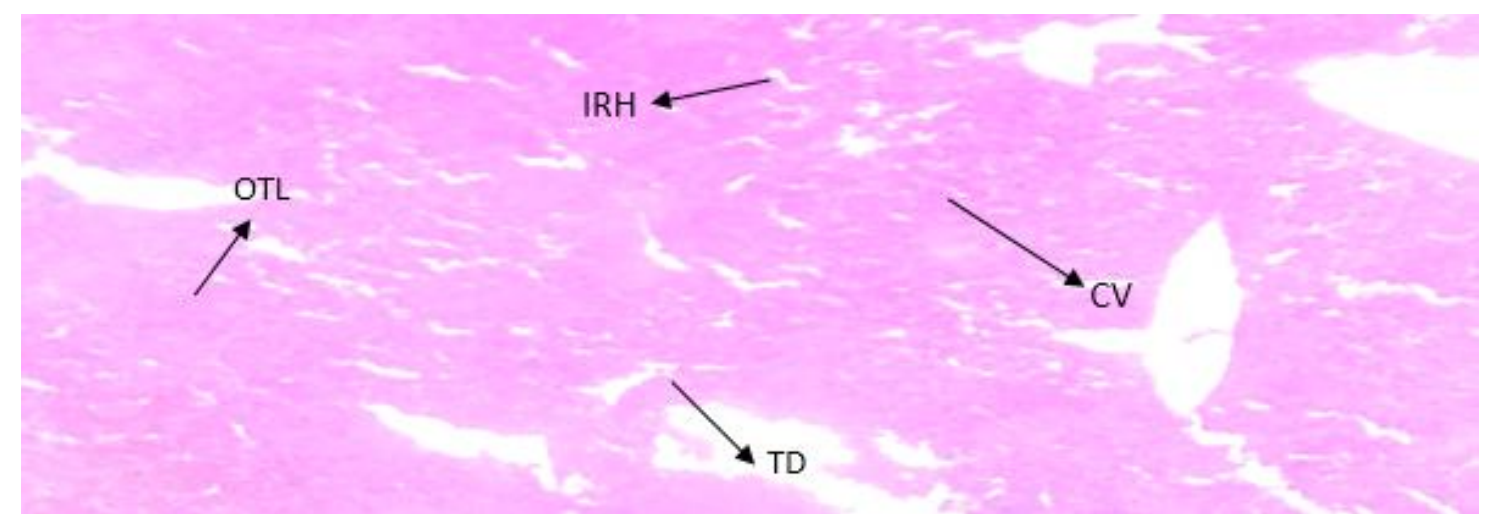

Figure 2D. Photomicrograph of the Kidney of $C$. gariepinus exposed to Sub lethal concentrations of chloramphenicol for 70 days at $60 \mathrm{mg} / \mathrm{l}$, showing various degrees of injuries which includes: dilation (D) Intra-renal hemorrhage (IRH), cytoplasmic vacuolation (CV), hyperplasia (Hy) and tissue degeneration (TD) (Mag.x60). 


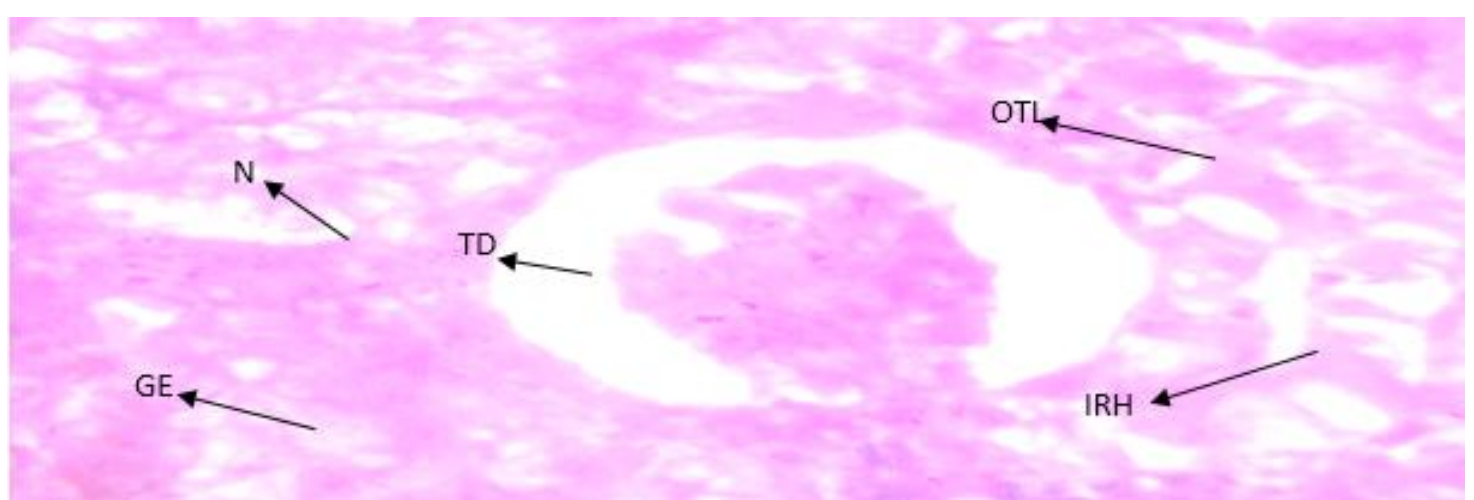

Figure 2E. Photomicrograph of the Kidney of $C$. gariepinus exposed to Sub lethal concentrations of chloramphenicol for 70 days at $80 \mathrm{mg} / \mathrm{l}$, showing various degrees of injuries which includes: necrosis $(\mathrm{N})$ in the tissue, dilation of the blood vessels (D), intra-renal hemorrhage (IRH), hyperplasia (Hy) tissue degeneration (TD); occlusion of tubular lumen (OTL), expansion of glomerulus (GE) (Mag.x60).

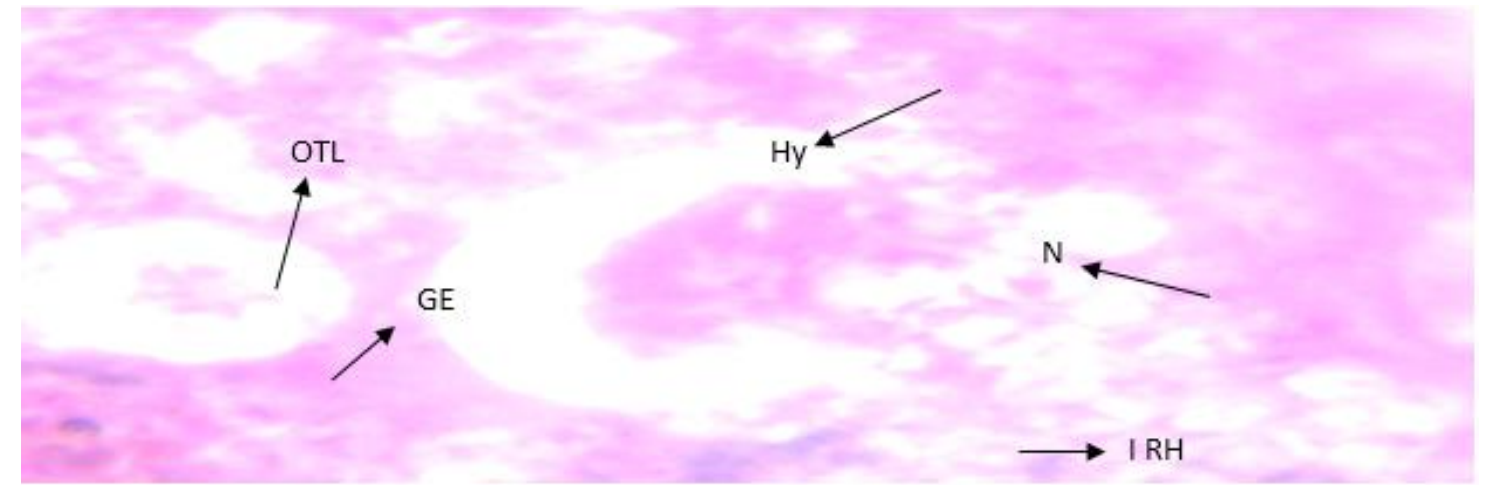

Figure 2F. Photomicrograph of the Kidney of $C$. gariepinus exposed to Sub lethal concentrations of chloramphenicol for 70 days at $100 \mathrm{mg} / \mathrm{l}$ showing various degrees of injuries which includes: necrosis $(\mathrm{N})$ in the tissue, dilation of the blood vessels (D), intra-renal hemorrhage (IRH), hyperplasia (Hy) tissue degeneration (TD); occlusion of tubular lumen (OTL), expansion of glomerulus (GE) (Mag.x60).

\section{Conclusion}

In this experiment, the African catfish C. gariepinus was used as a test organism. C. gariepinus is the most widely cultivated fish species in Africa and Asia due to its inherent advantages. The species is of great economic importance in both fisheries and fish culture. The findings from this research reveal that antibiotic use in rearing aquacultural species has deleterious effects. The increasing use of various antibiotics in fish culture has resulted in a rise in bioaccumulation of these chemicals in the tissue of cultured organisms. Observed histopathological alterations in the liver and kidney were intra-hepatic hemorrhage, hypertrophic hepatocytes, tissue degeneration, cytoplasmic vacoulation, edema, dilation, cellular necrosis; occlusion of tubular lumen, expansion of glomerulus, reduction of Bowman's space, congestion of blood vessels; degeneration and degeneration of epithelial and marginal cells in the test organs. The gravity of the lacerations along the concentration gradient was noted to be relatively proportional dosage. The monitoring and assessment of histopathological distortion in fish organs like liver and kidney might be an excellent technique for determining the side-effects of antibiotic drugs in the field and laboratory experiments.
Therefore, the use of antibiotic toxicological studies on aquatic organisms is imperative to enable aquaculturists evaluate its noxious effect most especially in the essential organs of fish.

\section{Acknowledgement}

The authors are grateful to Mrs. Chioma Awoke for type-setting the manuscript.

\section{References}

Abdelhamid, A.M., \& El-Ayouty, S.A. (1991). Effect on catfish Clarias lazera composition of ingestion comparing water contaminated with lead or aluminum compounds. Arch Tierernahr. 41(7-8): 757-763.

https://www.ncbi.nlm.nih.gov/pubmed/1789741

Al-Yousuf, M.H., El-Shahawi, M.S., \& Al-Ghais, S.M. (2000). Trace metals in liver, skin and muscle of Lethrinus lentjan fish species in relation to body length an pharmacokinetics and residues of chloramphenicol in the chicken. Journal of Veterinary Pharmacology, 17(1): 52-58.

Amrevuawho, M.O., Akinyemi, A.A., Oyewusi, J.A., Bankole, O.M., \& Ezeri, G.N.O. (2016). Effects of onion (Allium cepa) and chloramphenicol on haematological parameters, histopathology and survival of catfish 
Clarias gariepinus (Burchel 1822) sub adult infected with Pseudomonas aerugonosa. Vom Journal of Veterinary Science, 11: 1- 12. http//doi.org/98.1479032521

Angulo, F.J. (2000). Antimicrobial agents in aquaculture: potential impact on health. APUA Newsletter. 18: 1-6.

APHA (American Public Health Association), (2002). Standard Methods for Examination of Water and Wastewater, 20th edition. American Public Health Association, Washington DC. https://www.mwa.co.th/download/file_upload/SMWW _1000-3000.pdf.

Bancroft, J.D., \& Stephen, A. (1990). Theory and Practice of histological techniques, $3^{\text {rd }}$ Edition. London. Medical Division of Longman Group, 1372 pp.

Braunbeck, T., Storch, V., \& Bresch, H. (1990). Species-specific reaction of liver ultrastructure in zebra fish, Brachydanio rerio and trout, Salmo gairdneri after prolonged exposure to 4-chloroaniline. Archives of Environmental Contamination and Toxicology, 19: 405-418. https://link.springer.com/article/10.1007/BF01054986

Byzkowski, J. (1976). The mode of action of P, PDDT on mammalian mitochondria. Toxicology, 6, 309-314. https://www.sciencedirect.com/science/article/pii/030 0483X76900342

Camargo, M.M.P., \& Martinez, C.B.R. (2007). Histopathology of gills, kidney and liver of a Neotropical fish caged in an urban stream. Neotropical Ichthyology, 5(3): 327336.

http://dx.doi.org/10.1590/S1679-62252007000300013

Dienye, H.E., \& Olumuji, O.K. (2014). Growth performance and haematological responses of African mud catfish Clarias gariepinus fed dietary levels of Moringa oleifera leaf meal Net Journal of Agricultural Science, 2(2): 79-88.

Fanta, E., Rios, F. S., Romao, S., Vianna, A.C.C., \& Freiberger, S. (2003). Histopathology of the fish Corydoras paleatus contaminated with sublethal levels of organophosphorus in water and food. Ecotoxicology and Environmental Safety, 54: 119-130. https://www.ncbi.nlm.nih.gov/pubmed/12550089

Faturoti, E.O. (1989). Effects of supplementary feeding and organic manuring on the production of African Catfish; Clarias gariepinus (Burchell 1922), Journal of West African Fisheries, 4: 187-195.

Figueiredo-Fernandes, A., Ferreira-Cardoso, J.V., GarciaSantos, S., Monteiro, S.M., Carrola, J., Matos, P., \& Fontaínhas-Fernandes, A. (2007). Histopathological changes in liver and gill epithelium of Nile tilapia, Oreochromis niloticus exposed to waterborne copper. Pesq. Vet. Bras., 27(3): 103-109. http://www.scielo.br/pdf/pvb/v27n3/04.pdf

Gernhofer, M.M, Pawet, M., Schramm, M., Müller, E., \& Triebskorn, R. (2001). Ultrastructural biomarkers as tools to characterize the health status of fish in contaminated streams. Journal of Aquatic Ecosystem, Stress and Recovery, 8(22): 241-260. doi: 10.1023/A:1012958804442.

Gingerich, W.H. (1982). Hepatic toxicology of fishes. In Aquatic toxicology, (Ed L.J. Weber). New York, Raven press, 55 pp.

Hibiya, T. (1982). An Atlas of Fish Histology: Normal and Pathological Features. Japan: Kodansha Ltd, 82-90 pp.

Hinton, D.E., \& Lauren, D.J. (1990). Liver structural alterations accompanying chronic toxicity in fishes: potential biomarkers of exposure. In J.F. McCarthy \& L.R. Shugart
(Eds.), Biomarkers of Environmental Contamination (pp. 17-52) Lewis Publishers, $445 \mathrm{pp}$.

Hunter, J.B., Ross, S.L., \& Tannahill, J. (1980). Aluminium pollution and fish toxicity. Journal of water Pollution Control Federation, 79, 413-420. https://www.epa.gov/sites/production/files/2018-

12 /documents/aluminum-final-national-recommendedawqc

Jonathan, P., \& Nicolas, V. (2005). Household disposal of pharmaceuticals as a pattern for aquatic contamination in the United Kingdom. Environmental Health Perspective, 113, 1705-1711.

https://www.ncbi.nlm.nih.gov/pmc/articles/PMC13149 09/

Joseph, P.V., \& Nimmy, M.V. (2018). Effect of lead nitrate on the histopathology of the gill, liver and kidney of the freshwater fish, Cirrhinus mrigala, European Journal of Pharmaceutical, 5(2): 416-420.

Manoraham, S. (2014). Pharmaceutical residues in India: Impact on aquatic environment. Current science 107(10): 1634-1635.

Mollendroff, T. (1973). Cytology and cell physiology. 3rd Edition. New York. Academic Press, 234 pp.

Pacheco, M., \& Santos, M.A. (2002). Biotransformation, genotoxic and histopathological effects of environmental contaminants in European eel Aquilla aquilla. Ecotoxity and Environmental Safety, 53: 331347.

https://media.dojmt.gov/wp-content/uploads/nrdpyellowstone-restoration.pdf

Peebuaa, P., Kruatrachuea, M., Pokethitiyooka, P., \& Kosiyachindaa, P. (2006). Histological Effects of Contaminated Sediments in Mae Klong River Tributaries, Thailand, on Niletilapia, Oreochromis niloticus. Science Asia, 32: 143-150.

http://scienceasia.org/2006.32.n2/v32_143_150.pdf

Rahman, M.Z., Hossain, Z., Mullah, M.F.R., \& Ahmed, G.U. (2002). Effects of diazinon 60EC on Anabus testudineus, Channa punctatus and Barbades gomonotus, NAGA. The ICLARMS Quarterly, 25: 811-815.

Rodrigues, E.L., \& Fanta, E. (1998). Liver histopathology of the fish Brachydanio rerio after acute exposure to sublethal levels of the organophosphate Dimetoato 500. RevistaBrasileira de Zoologia, 15: 441-450. http://dx.doi.org/10.1590/S0101-81751998000200014

Rosseland, B.O., Eldhuset, T.D., \& Staurnes, M. (1990). Environmental effects of aluminum. Environmental and Geochemical Health, 12: 17-27.

Sarwer, Md. G., Rony, Md. M.H., Sharmin, MSt. S., Chowdhury, A.K.J., \& Bhowmik, S. (2017). ELISA validation and determination of cut-off level for chloramphenicol (CAP) residues in shrimp and fish. Our Nature 15(1-2): 13-18. DOI: http://dx.doi.org/10.3126/on.v15i1-2.18789

Sanad, S.M., El-Nahass, E.M., Abdel-Gawad, A.M., \& Aldeeb, M. (1997). Histochemical studies on the liver of mice following chronic administration of sodium barbitone. Journal of Zoological Sciences, 22(C): 127-165.

Saravpreet, K., Kuldeep, S.K., \& Jasjit, K.K. (2018). Heavy metal induced histopathological alterations in liver, muscle and kidney of freshwater cyprinid, Labeo rohita (Hamilton). Journal of Entomology and Zoology Studies, 6(2): 2137 2144.

Solbe, J.F. (1995). Fresh Water. In P. Collins (ed), Handbook of Ecotoxicology. Osneymeed: Black Well Science Ltd. 683 pp. 
Takashima, F., \& Hibiya, T. (1995). An Atlas of Fish Histology: Normal and pathogical features, $2^{\text {nd }}$ ed. Tokyo: Kodansha Ltd, $45 \mathrm{pp}$.

Teugels, G., Sudarto, G., \& Pouyaud, L. (2001). Description of a New Clarias Species from Southeast Asia Based on Morphological and Genetical Evidence (Siluriformes, Clariidae) Zoological Studies 25(1): 81-92.

Thophon, S.M., Kruatrachue, E.S., Upathan, P., Pokethitiyook, S., Sahaphong, S., \& Jarikhuan, C. (2003).
Histopathological alterations of white seabass, Lates calcarifer in acute and subchronic cadmium exposure. Environmental Pollution, 121: 307-320.

Van der Oost, R., Beyer, J., \& Vermulen, N.P.E. (2003). Fish bioaccumulation and biomarkers in environmental risk assessment: A review. Environmental Toxicology and Pharmacology, 13: 57-149.

https://www.ncbi.nlm.nih.gov/pubmed/21782649 